American Journal of

Health, Medicine and Nursing Practice (AJHMN)

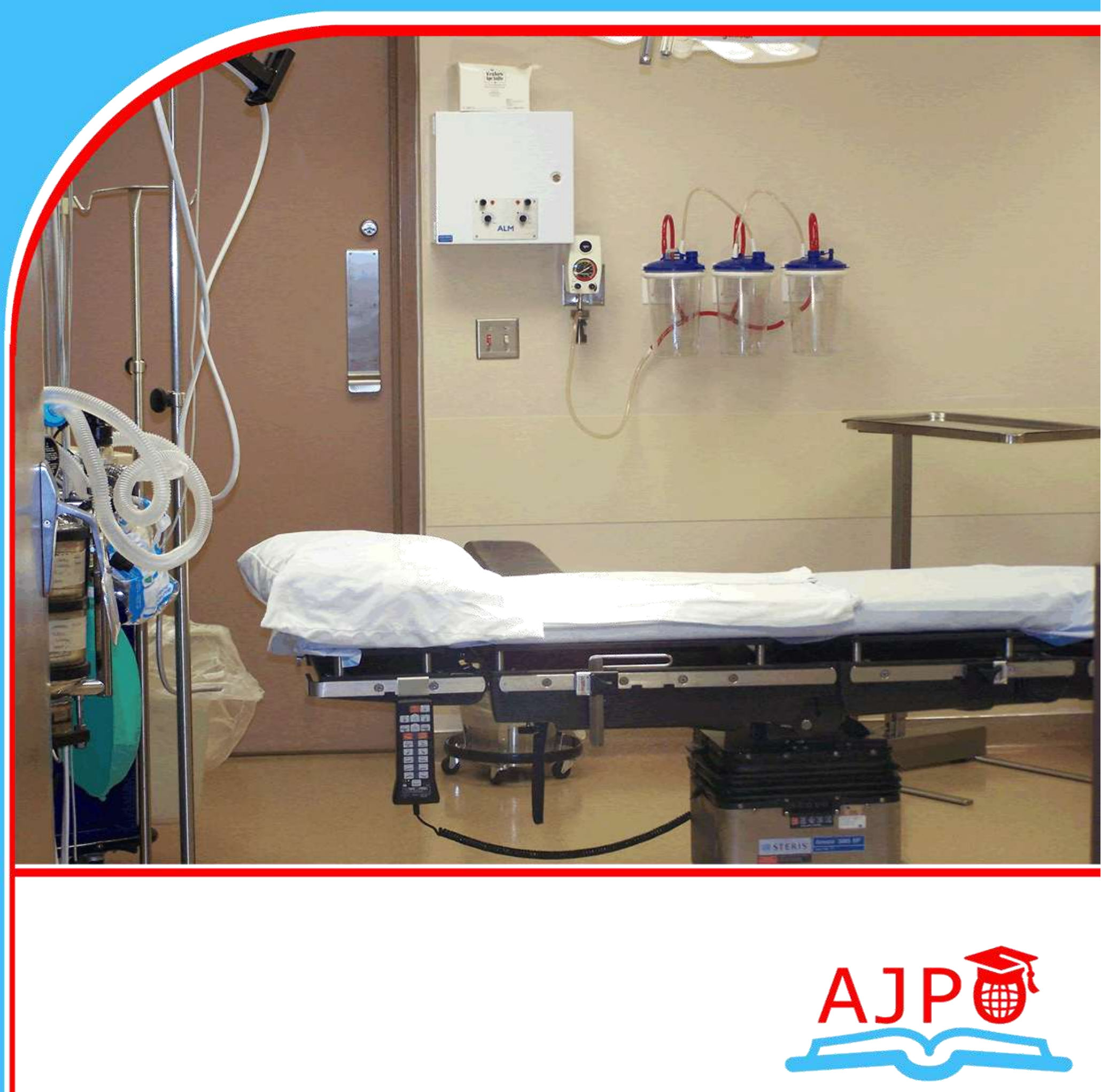




\title{
REFLECTIVE PRACTICE: ITS KNOWLEDGE, PRACTICE AND PERCEPTION DURING COVID-19 AMONG PAEDIATRIC NURSING STUDENTS
}

\author{
Ruth Nimota Nukpezah ${ }^{* 1}$ \\ School of Nursing and Midwifery, Department of Preventive Health Nursing \\ University for Development Studies, Tamale, Ghana \\ https://orcid.org/0000-0002-4560-3329 \\ *Corresponding Author’s Email: nimotaruth@gmail.com \\ Alhassan Tia Fuseini ${ }^{2}$ \\ Tamale Teaching Hospital, Ghana, Department of Nursing \\ Email: mrfuzzy3395@gmail.com \\ Fusseini Bawa ${ }^{3}$ \\ East Mamprusi Municipal Health Directorate, Department of Nursing \\ Email: fuseini.junior@yahoo.com \\ Alhassan Ayisha Napari ${ }^{4}$ \\ Tamale Central Hospital, Department of Nursing \\ Email: nalhassan93@yahoo.com \\ Gifty Wuffele 5
}

School of Nursing and Midwifery, Department of Midwifery and Women's Health

University for Development Studies, Tamale, Ghana

Email: gwuffele@yahoo.com

Obed Duah Kwaku Asumadu6

School of Nursing and Midwifery, Department of Nursing

University for Development Studies, Tamale, Ghana

Email: asumaduobed@yahoo.com

Wisdom Peprah ${ }^{7}$

School of Allied Health Sciences, Department of Nutritional Sciences

University for Development Studies, Tamale, Ghana

Email: pwisdom466@gmail.com

Richard Opoku Asare ${ }^{8}$

College of Nursing, Ntotroso, Department of Nursing

https://orcid.org/0000-0002-9392-9569

Email: asareor@gmail.com 


\section{ABSTRACT}

Purpose: This study sought to explore the knowledge level, practice and perception of the usefulness of reflective practice among pediatric nursing students in the face of the COVID-19 pandemic.

Methodology: A quantitative descriptive cross-sectional study was used in carrying out the study. The study was conducted among pediatric nursing level 300 and 400 students of the University for Development Studies, Tamale, with an age range between 17 and 38. A structured questionnaire in electronic form (using Google forms) was administered to respondents through their class social media (WhatsApp) platform. Data analyses were done using the Statistical Package for Social Sciences (SPSS) version 21 and Microsoft Excel. The Fisher Exact Test was used to determine how statistically significant independent variables influence the dependent variables.

Results: Findings showed that $88.5 \%$ (54/61) of the students knew reflective practice, $98.4 \%$ of them practised reflection. All respondents agreed that reflective practise has a positive impact on personal and professional development. No association existed between the age of respondents and knowledge of reflection (Fisher's exact test $=5.18 ; \mathrm{p}=0.159$ ). However, there were significant differences between the sex of respondents and knowledge of reflection (Fisher's exact test $=12.09$; $\mathrm{p}=0.001$ ) and between the class of respondents and their level of knowledge (Fisher's exact test $=10.90 ; \mathrm{p}=0.004)$.

Conclusion: Reflection is a very useful professional and personal development tool that yields positive care and learning outcomes when effectively practised. Hospitals and educational institutions should develop processes and practices that make refective practice an early and routine part of an everyday classroom and clinical practice.

Recommendation: Reflection should be developed as a course and be inculcated into the firstdegree nursing curriculum in universities.

Keywords: Reflective Practice, Knowledge, Perception, Paediatric Nursing Students 
American Journal of Health, Medicine and Nursing Practice

ISSN 2520-4017 (Online)

Vol.6, Issue 3, pp 39 - 52, 2021

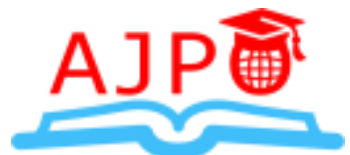

Www.ajpojournals.org

\section{INTRODUCTION}

The COVID-19 pandemic has had a significant impact on our society, especially in the healthcare sector due to an increase in hospital inpatients and outpatients' rates. This situation could jeopardize the learning and practice of nursing students due to its concomitant effects (Ulenaers et al., 2021). COVID-19 has indeed caused havoc in hospitals and educational institutions (d'Aquin, 2020; Gross et al., 2021; Ulenaers et al., 2021). Nursing institutions are bracing for specific challenges related to issues concerning the reflective practice of nursing students.

Nursing is a career that entails delivering patient care and necessitates a continuous reflection on the actions taken when providing that care to ensure that patients and their families receive quality care (Anderson, 2019), especially as we are not in normal times. Nurses need to reflect on actual experiences to deal with current clinical challenges. Reflection is an active process in which nursing students or nurses identify the situation, recognize their emotional response, examine their thoughts and feelings internally, evaluate their actions and the situation, and prepare a new action as a result of the theory-practice gap identified (Tashiro et al., 2013). Pediatric nursing students are responsible for caring for not just children, but also the children's families as well. When working with these vulnerable groups of people, safety is paramount.

Nurses today work in a highly complex, dynamic, and ever-changing system while providing a variety of healthcare services. To deal with these changes, nursing students must improve their clinical practice learning through the use of reflective practice (Mirlashari et al., 2017; Reljić et al., 2019). In general, through reflection, students can observe and focus on the experience frame of their lives to resolve contradictions in practice (Ruiz-López et al., 2015).

Reflection on clinical experience by nursing students during the clinical learning process is important in developing such students' abilities. According to the results of some studies, reflection has resulted in outcomes such as improving student-teacher relationships, bridging the gap between theory and practice, deep learning, and enhancing critical thinking skills (Achi et al., 2016; Cecilia \& Katherine, 2020; Naber \& Wyatt, 2014).

Reflective practice is recognized as an educational need in the nursing industry for enhancing learners' knowledge and understanding, this concept needs more in-depth examinations (RuizLópez et al., 2015). According to research conducted in Ghana, nursing students typically do not provide the necessary care to patients at the bedside, indicating a gap between theory and practice (Yiridomoh et al., 2020). In recent years, the large gap between learning activities and clinical nursing services has caused a nursing crisis and sparked public criticism of the quality of nursing care in developing counties (Van Rensburg et al., 2018). Ensuring professional competency in clinical decision making necessitates critical thinking through the act of constant reflective practice in all ward activities.

The practice of reflection in learning and job sites has become common across many disciplines around the world (Achi et al., 2016). Nurses in many developing countries, especially Ghana, utilize the nursing process approach as a tool to provide quality and individualized patient's care (Mahlanze \& Sibiya, 2017). Complete reliance on the nursing process alone cannot provide the knowledge and competency needed to give quality care for patients (Agyeman-Yeboah et al., 2017). Hence, there is a need to integrate reflective practice to close the theory-practice gap to 
optimize the treatment that is provided to patients. A study by Boso and colleagues (2020) also noted that nursing is one of those professions in healthcare that has adopted reflection and critical thinking with great reverence due to its importance in professional development. It stated further that whiles some African countries use reflection and critical thinking in both learning and practice, there is no published evidence to show that that is also the case in Ghana (Boso et al., 2020).

Many students of various professions, including nursing, especially undergraduate students, pass through universities without ever hearing the term "reflection" as a tool for professional learning, both in school and lifelong at the job site (Bruni-Bossio \& Delbaere, 2021). It is hoped that the understanding of students' knowledge, perceptions, and practice of reflection will help promote self-awareness and promote best practice. It is hoped that this skill is maintained, developed, and strengthened for the future of nursing education. It is further hoped that the uptake of these current research findings into policy and practice in Ghana will help promote the development of the nursing profession.

A study conducted in Iran showed that pediatric nurses face emotional and psychological challenges, but weekly meetings with their instructors to discuss their journal entries aided students' transition through the practicum. Thus, it promoted pediatric nursing students emotional coping and integrated learning during demanding clinical rotations (Mirlashari et al., 2017). The findings of reflective practice among pediatric nurses in industrialized counties might be different among other pediatric nurses from developing nations such as Ghana, as a result of contextual differences in practical settings. Yet, no such study has been conducted concerning this issue among nurses in Ghana and non among pediatric nurses in Ghana. Therefore, this study assessed the Ghanaian pediatric nursing students' knowledge, practice, and perception of reflective practice.

\section{METHODOLOGY}

This study adopted a descriptive cross-sectional study design. The quantitative approach was employed to assess and ascertain the knowledge, practice, and perception of reflective practice among pediatric nursing students in Tamale. The study was conducted among pediatric nursing levels 300 and 400 students of the University for Development Studies (UDS), Tamale.

After the institutional review board approved the study protocol, levels 300 and 400 pediatric nursing students of the UDS Tamale were recruited for the study. The respondents age range was within 17 and 38 years. This study was done from January 2021 to May 2021. A convenience sampling method was used to select a sample size of 100 students. Due to attrition, only 61 out the 100 respondents submitted their responses for the study.

A structured questionnaire in electronic form (using Google forms) was administered to respondents through their class social media (WhatsApp) platform after consent was sorted from them and an explanation was given on the terms of participation. The questionnaire comprised the knowledge level of respondents about reflection, whether or not respondents practice it, and where how respondents perceived the usefulness of reflective practice, and as well as their sociodemographic characteristics.

Descriptive statistics, which involves frequencies and percentages, were used in representing data on the socio-demographic characteristics of the respondents. The cumulative score was used to calculate the knowledge, practice, and perception of students. Under the knowledge, seven items 
(questions) were used to assess their knowledge level. A score of 0-3 was categorized as inadequate knowledge whilst a score of 4-7 was considered as knowledgeable. A five-point Likert scale was used to determine how students perceived reflective practice. A score of 60 marks from the 12 items was earmarked as the maximum score. From 0\%-20\% score from a student was considered as bad perception, $21 \%-40 \%$ was categorized as moderate, and $41 \%-60 \%$ was good perception.

The Fisher Exact Test was used to cross-tabulate the variables to see the outcomes that exist between the independent and dependent variables and to determine how significantly the variables statistically influence the outcomes of the study. Data entry and its analysis were done using the Statistical Package for Social Sciences (SPSS) version 21 and Microsoft Excel.

\section{RESULTS}

\section{Socio-demographic characteristics}

The majority of the pediatric student nurses $41(67.2 \%)$ were between the ages of 27 and 32 . Female students in pediatric nursing 38 (62.3\%) dominated the study, and $72.1 \%$ (44/61) were those in level 300 of their study at the university. Table 1 depicts the socio-demographic data of the respondents.

Table 1: Socio-demographic characteristics

\begin{tabular}{|c|c|c|}
\hline Variable & $\begin{array}{c}\text { Frequency } \\
(n=61)\end{array}$ & $\begin{array}{c}\text { Percentage } \\
(\mathbf{1 0 0 \%})\end{array}$ \\
\hline \multicolumn{3}{|l|}{ Age } \\
\hline$\leq 20$ & 1 & 1.6 \\
\hline$-21-26$ & 3 & 4.9 \\
\hline$-\quad 27-32$ & 41 & 67.2 \\
\hline $33+$ & 16 & 26.2 \\
\hline \multicolumn{3}{|l|}{ Sex } \\
\hline Male & 23 & 37.7 \\
\hline - Female & 38 & 62.3 \\
\hline \multicolumn{3}{|l|}{ Level of respondents } \\
\hline-400 & 17 & 27.9 \\
\hline 300 & 44 & 72.1 \\
\hline
\end{tabular}

\section{Knowledge level of pediatric students about reflective practice}

Table 2 shows the results of respondents' level of knowledge about reflective practice. Concerning what reflective practice meant to the students, 33 (54.1\%) said reflective practice means reviewing actions. In answering where the reflective practice was learnt from, the majority $91.8 \%$ (56/61) claimed to have learnt it from a lecturer in the classroom as a teaching and learning method. For the length of time that students have learnt reflective practice, $53(86.9 \%)$ admitted to having the experience for one to two years. When they were allowed to describe the learning process regarding reflective practice, $88.5 \%(54 / 61)$ said it was normal as any lesson. When the students were quizzed further as to how reflections may influence their actions and reactions towards situations, the majority $59(96.7 \%)$ affirmed that it influences them, as it helps $39(63.9 \%)$ of the 
students by guiding the selection of actions in similar situations. The majority of the students 52 $(85.2 \%)$ had a view about the use of reflection as social interaction with friends.

In assessing the overall knowledge of students about practising reflection, the data indicated that $33(54 \%)$ were knowledgeable while $28(46 \%)$ of them were not knowledgeable.

Table 2: Knowledge level of students about reflective practice $(n=61)$

\begin{tabular}{|c|c|c|}
\hline Variable & Frequency & Percentage \\
\hline \multicolumn{3}{|l|}{ Meaning of reflective practice to you } \\
\hline - Own definition of a happened event & 5 & 8.2 \\
\hline - Looking back & 10 & 16.4 \\
\hline - Reviewing actions & 33 & 54.1 \\
\hline - Critical thinking & 13 & 21.3 \\
\hline \multicolumn{3}{|l|}{ Reflection/reflective practice learnt from where } \\
\hline $\begin{array}{l}\text { - Lecturer in the classroom as a teaching and learning } \\
\text { method }\end{array}$ & 56 & 91.8 \\
\hline - An explanation from a colleague at school/work & 1 & 1.6 \\
\hline - Senior staff & 1 & 1.6 \\
\hline - The internet & 1 & 1.6 \\
\hline - Clinical area & 2 & 3.3 \\
\hline \multicolumn{3}{|l|}{ Length of learning reflection } \\
\hline - 1-2 years & 53 & 86.9 \\
\hline - $\quad 2-4$ years & 2 & 3.3 \\
\hline - $\quad 5-6$ years & 3 & 4.9 \\
\hline$-6+$ years & 3 & 4.9 \\
\hline \multicolumn{3}{|l|}{ Description of reflection's learning process } \\
\hline - Normal as any lesson & 54 & 88.5 \\
\hline - Easy & 1 & 1.6 \\
\hline - Difficult & 6 & 9.8 \\
\hline \multicolumn{3}{|l|}{$\begin{array}{l}\text { Reflection influencing your actions and reactions towards } \\
\text { situations }\end{array}$} \\
\hline- Yes & 59 & 96.7 \\
\hline- No & 2 & 3.3 \\
\hline \multicolumn{3}{|l|}{ Reflection on a difficult situation help you in a way } \\
\hline - It guides the selection of actions in similar situations & 39 & 63.9 \\
\hline - It leads to a better understanding of the situation & 8 & 13.1 \\
\hline - It results in emotional growth & 1 & 1.6 \\
\hline $\begin{array}{l}\text { - It leads to early recognition of the similar event and } \\
\text { prompt actions to avert it }\end{array}$ & 13 & 21.3 \\
\hline
\end{tabular}


American Journal of Health, Medicine and Nursing Practice

ISSN 2520-4017 (Online)

Vol.6, Issue 3, pp 39 - 52, 2021

www.ajpojournals.org

Table 2: Knowledge level of students about reflective practice $(n=61)-$ cont'd

\begin{tabular}{lcc}
\hline Variable & Frequency & Percentage \\
\hline Views about the use of reflection in a personal situation & & \\
$-\quad$ Social interaction with friends & 52 & 85.2 \\
$-\quad$ Interaction with family & 5 & 8.2 \\
$-\quad$ Religious practices & 4 & 6.6 \\
\hline \multicolumn{4}{c}{ Overall knowledge level of students on reflective practice } \\
\hline Knowledgeable & 33 & 54 \\
Not knowledgeable & 28 & 46 \\
\hline
\end{tabular}

\section{Practice of reflection}

Results from the data indicated that $60(98.4 \%)$ of the students practice reflection. Out of the students who practice reflection, $26(43.3 \%)$ do it often, $17(28.3 \%)$ do it very often, and 17 $(28.3 \%)$ do it sometimes. It was noted that $15(25.0 \%)$ said they practised it at work While one $(1.7 \%)$ considered practising it during emergencies. Most of the students $78.3 \%(n=47 / 61)$ agreed that the practice of reflection shapes future actions or interventions in similar situations While one (1.7\%) said it boosts their confidence. More so, 49 (80.3\%) claimed to have ever had any experience on which they had to think and reflect more. Most of the students $32(52.5 \%)$ who had ever had this experience said it resulted in a modification of their future actions in the same situation. This influenced $59(96.7 \%)$ about how they see and perceive situations. It was noted that $27(44.3 \%)$ said the emotional consequences were the challenge associated with learning and practice of reflection as shown in Table 3 below. 
American Journal of Health, Medicine and Nursing Practice

ISSN 2520-4017 (Online)

Vol.6, Issue 3, pp 39 - 52, 2021

www.ajpojournals.org

Table 3: Practice of reflection $(n=61)$

\begin{tabular}{|c|c|c|}
\hline Variable & Frequency & Percentage \\
\hline \multicolumn{3}{|l|}{ Do you practice reflection } \\
\hline - Yes & 60 & 98.4 \\
\hline$-\quad$ No & 1 & 1.6 \\
\hline \multicolumn{3}{|l|}{ How often do you practice it } \\
\hline - Often & 26 & 43.3 \\
\hline - Very often & 17 & 28.3 \\
\hline - Sometimes & 17 & 28.3 \\
\hline \multicolumn{3}{|l|}{ Where do you practice reflection? } \\
\hline - At work & 15 & 25.0 \\
\hline$-\quad$ School & 3 & 5.0 \\
\hline - In emergencies & 1 & 1.7 \\
\hline - Every time & 17 & 28.3 \\
\hline - Most times & 24 & 40.0 \\
\hline \multicolumn{3}{|l|}{ What makes you practice reflection } \\
\hline - It provides a satisfactory outcome of learning/ care & 8 & 13.3 \\
\hline - It builds emotional maturity as I reflect on negative events & 4 & 6.7 \\
\hline - It boosts confidence & 1 & 1.7 \\
\hline - It shapes future actions/interventions in similar situations & 47 & 78.3 \\
\hline \multicolumn{3}{|l|}{$\begin{array}{l}\text { Do you have any experience on which you have to think and } \\
\text { reflective more? }\end{array}$} \\
\hline- Yes & 49 & 80.3 \\
\hline- No & 12 & 19.7 \\
\hline \multicolumn{3}{|l|}{ What was the outcome of this reflection } \\
\hline $\begin{array}{l}\text { - It resulted in modification of my future actions in the same } \\
\text { situation }\end{array}$ & 32 & 52.5 \\
\hline - It provided satisfactory outcomes on similar events & 25 & 41.0 \\
\hline - It enhanced my emotional strength & 2 & 3.3 \\
\hline - I regretted practising reflection & 2 & 3.3 \\
\hline \multicolumn{3}{|l|}{ Has it influenced how you see and perceive situations } \\
\hline - Yes & 59 & 96.7 \\
\hline- No & 2 & 3.3 \\
\hline \multicolumn{3}{|l|}{$\begin{array}{l}\text { Do you observe a difference between yourself and those who } \\
\text { do not practice reflection?. }\end{array}$} \\
\hline - Yes & 43 & 70.5 \\
\hline - $\quad$ No & 2 & 3.3 \\
\hline - Maybe & 16 & 26.2 \\
\hline \multicolumn{3}{|l|}{$\begin{array}{l}\text { Have you noticed differences in learning and care outcomes } \\
\text { between yourself and those who practice reflection? }\end{array}$} \\
\hline - Yes & 49 & 80.3 \\
\hline$-\quad$ No & 12 & 19.7 \\
\hline
\end{tabular}


American Journal of Health, Medicine and Nursing Practice

ISSN 2520-4017 (Online)

Vol.6, Issue 3, pp 39 - 52, 2021

www.ajpojournals.org

Table 3: Practice of reflection $(n=61)-$ Cont'd

\begin{tabular}{lcc}
\hline Variable & Frequency & Percentage \\
\hline $\begin{array}{l}\text { Are there challenges associated with learning and practice of } \\
\text { reflection? }\end{array}$ & & \\
$-\quad$ Lack of knowledge about reflection & 13 & 21.3 \\
$-\quad$ Lack of time & 21 & 34.4 \\
- Emotional consequences & 27 & 44.3 \\
Based on your answers given, we will consider recommending & & \\
reflection and reflective writing to any colleague? & & \\
$\quad-\quad$ Yes & 60 & 98.4 \\
$-\quad$ No & 1 & 1.6 \\
\hline
\end{tabular}

Perception of students about the usefulness of reflection

On the students' perception of reflection and its usefulness, $42(68.9 \%)$ of the students agreed that reflection represents very useful in critical thinking skill development, $23(37.7 \%)$ perceived reflection as useful in the synthesis of classroom and clinical knowledge, $6(9.8 \%)$ perceived reflection as useful in self-awareness creation, $44(72.1 \%)$ said reflection is very useful in professional growth and promotion of professional behaviours and $11(18.0 \%)$ said reflection is useful in the creation of awareness of emotional responses, personal bias and beliefs. This is illustrated in the table below.

Table 4: Perception of students about the usefulness of reflection

\begin{tabular}{lccccc}
\hline \multicolumn{1}{c}{ Item description } & $\begin{array}{c}\text { Representing } \\
\text { very useful }\end{array}$ & Useful & $\begin{array}{c}\text { Somehow } \\
\text { useful }\end{array}$ & $\begin{array}{c}\text { Not all } \\
\text { that } \\
\text { useful }\end{array}$ & $\begin{array}{c}\text { Not } \\
\text { useful at } \\
\text { all }\end{array}$ \\
\hline $\begin{array}{l}\text { Critical thinking skill } \\
\text { development }\end{array}$ & $42(68.9 \%)$ & $14(23.0 \%)$ & $5(8.2 \%)$ & $0(0.0 \%)$ & $0(0.0 \%)$ \\
\hline $\begin{array}{l}\text { Synthesis of classroom } \\
\text { and clinical knowledge }\end{array}$ & $29(47.5 \%)$ & $23(37.7 \%)$ & $9(14.8 \%)$ & $0(0.0 \%)$ & $0(0.0 \%)$ \\
\hline $\begin{array}{l}\text { It leads to self- } \\
\text { awareness creation }\end{array}$ & $36(59.0 \%)$ & $19(31.1 \%)$ & $6(9.8 \%)$ & $0(0.0 \%)$ & $0(0.0 \%)$ \\
\hline $\begin{array}{l}\text { Professional growth and } \\
\text { promotion of } \\
\text { professional behaviors }\end{array}$ & $44(72.1 \%)$ & $8(13.1 \%)$ & $9(14.8 \%)$ & $0(0.0 \%)$ & $0(0.0 \%)$ \\
\hline $\begin{array}{l}\text { Creation of awareness } \\
\text { of emotional responses, } \\
\text { personal bias and } \\
\text { beliefs }\end{array}$ & $22(36.1 \%)$ & $28(45.9 \%)$ & $11(18.0 \%)$ & $0(0.0 \%)$ & $0(0.0 \%)$ \\
\hline
\end{tabular}


American Journal of Health, Medicine and Nursing Practice

ISSN 2520-4017 (Online)

Vol.6, Issue 3, pp 39 - 52, 2021

Www.ajpojournals.org

Table 4: Perception of students about the usefulness of reflection - cont'd

\begin{tabular}{lccccc}
\hline \multicolumn{1}{c}{ Item description } & $\begin{array}{c}\text { Representing } \\
\text { very useful }\end{array}$ & Useful & $\begin{array}{c}\text { Somehow } \\
\text { useful }\end{array}$ & $\begin{array}{c}\text { Not all } \\
\text { that } \\
\text { useful }\end{array}$ & $\begin{array}{c}\text { Not } \\
\text { useful at } \\
\text { all }\end{array}$ \\
\hline $\begin{array}{l}\text { Ability to correlate } \\
\text { theory with practice }\end{array}$ & $9(63.9 \%)$ & $14(23.0 \%)$ & $8(13.1 \%)$ & $0(0.0 \%)$ & $0(0.0 \%)$ \\
\hline $\begin{array}{l}\text { Ability to make } \\
\text { proactive decisions }\end{array}$ & $39(63.9 \%)$ & $10(16.4 \%)$ & $12(19.7 \%)$ & $0(0.0 \%)$ & $0(0.0 \%)$ \\
\hline $\begin{array}{l}\text { Improvement of } \\
\text { observation skills }\end{array}$ & $37(60.7 \%)$ & $13(21.3 \%)$ & $11(18.0 \%)$ & $0(0.0 \%)$ & $0(0.0 \%)$ \\
\hline $\begin{array}{l}\text { Stimulates towards } \\
\text { search for more } \\
\text { knowledge to be ready } \\
\text { for future }\end{array}$ & $38(62.3 \%)$ & $11(18.0 \%)$ & $12(19.7 \%)$ & $0(0.0 \%)$ & $0(0.0 \%)$ \\
\hline $\begin{array}{l}\text { Improve ability to } \\
\text { redefine experiences } \\
\text { and problems }\end{array}$ & $40(65.6 \%)$ & $13(21.3 \%)$ & $8(13.1 \%)$ & $0(0.0 \%)$ & $0(0.0 \%)$ \\
\hline $\begin{array}{l}\text { Ability to use past } \\
\text { experiences to prevent } \\
\text { future occurrences }\end{array}$ & $42(68.9 \%)$ & $9(14.8 \%)$ & $10(16.4 \%)$ & $0(0.0 \%)$ & $0(0.0 \%)$ \\
\hline $\begin{array}{l}\text { Helps in dealing with } \\
\text { difficult experiences }\end{array}$ & $34(55.7 \%)$ & $18(29.5 \%)$ & $9(14.8 \%)$ & $0(0.0 \%)$ & $0(0.0 \%)$ \\
\hline
\end{tabular}

Overall Perception about the Usefulness of Reflection

\begin{tabular}{lcc}
\hline Variable & Frequency $(\mathbf{n = 6 1 )}$ & Percentage (100\%) \\
\hline Moderate & 16 & 10.0 \\
Good & 45 & 90.0 \\
\hline
\end{tabular}

The overall scoring of students using the items as indicated in the table above shows that $10 \%$ $(n=16 / 61)$ of the students have a moderate perception about the usefulness of reflection. 
American Journal of Health, Medicine and Nursing Practice

ISSN 2520-4017 (Online)

Vol.6, Issue 3, pp 39 - 52, 2021

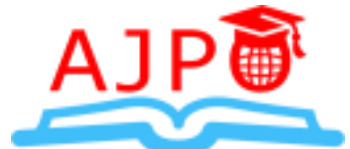

www.ajpojournals.org

\section{DISCUSSION}

This study assessed the Ghanaian pediatric nursing students' knowledge, practice, and perception of reflective practice. The majority of the respondents were females (44/61) as against 17 males. Noteworthy this figure is not surprising to see because generally, the nursing profession is femaledominated. Though the only person who responded to not practising reflection was a female, there was still more females (37) practising reflection compared to males (17).

Due to constantly changing medical reforms, the job of the nurse is constantly changing, particularly as they must develop a new understanding of diagnostics, care plans, medication and IV administration, and aspects such as discharge planning. As a result, they must constantly reflect on their actions when caring for their patients. In this current study, regarding knowledge of reflection, the results showed that more than half of the students $33(54.1 \%)$ said reflective practice means reviewing actions whilst $5(8.2 \%)$ maintained that it is the definition of a happening event. It was noted that $56(91.8 \%)$ learned reflection/reflective practice from a lecturer in the classroom as a teaching and learning method, $53(86.9 \%)$ learned reflection 1-2 years ago whilst $2(3.3 \%)$ learned it 2-4 years ago. The results showed that $54(88.5 \%)$ described the reflective learning process as normal as any lesson whilst six $(9.8 \%)$ described it as difficult. It has influenced 59 $(96.7 \%)$ of students' actions and reactions towards a situation and it helped $39(63.9 \%)$ of students by guiding the selection of actions in similar situations. The overall assessment of knowledge of the students' reflection, therefore, showed that $54 \%$ were knowledgeable whilst $46 \%$ of them were not knowledgeable. However, another study stated that clinical nurses lack critical thinking and critical reflective practice skills, according to the findings of a recent report, since they did not obtain systematic reflection training in nursing school (Graue et al., 2015). Anecdotal evidence has shown that student nurses' critical reasoning on knowledge has helped them prepare for clinical care.

The above assertion is contradicted by a qualitative study conducted at the University of Namibia, which had indicated that registered nurses in that country had poor knowledge of reflection practice (Nelumbu, 2013). This could be as a result of the fact that that study was conducted among graduate practising nurses pursuing a degree and not just all categories of nurses. However, the results of that study correlated with another study conducted at Western Cape Province, Stellenbosch, among 3rd-year baccalaureate nursing students regarding their use and application of reflection, and it was found that participants had a good understanding of reflection and admitted to having been engaging in various forms of reflective practices (Adams, 2018).

The result of the level of reflective practice showed that $60(98.4 \%)$ of the students practice reflection whilst one (1.7\%) does not. Out of the students who practice reflection, 26 (43.3\%) do it often, $17(28.3 \%)$ do it very often, and $17(28.3 \%)$ do it sometimes. It was noted that $15(25.0 \%)$ said they practice it at work whilst one $(1.7 \%)$ said he or she practices it in emergencies. Most of the students $(47,78.3 \%)$ agreed that the practice of reflection shapes future actions or interventions in similar situations whilst one (1.7\%) said it boosts their confidence. According to $49(80.3 \%)$ of the respondents, they have never had any experience on which they had to think and reflect more. Most of the students $32(52.5 \%)$ in this study who had ever had this experience said it resulted in a modification of their future actions in the same situation. This influenced $59(96.7 \%)$ students about how they see and perceive situations. It was noted that $27(44.3 \%)$ of the study participants 
said emotional consequences are the challenges associated with learning and the practice of reflection. The group had no preexisting empirical study which correlates or debunks this finding. However, Adams (2018) indicated that people practice reflection as he found that participants had a good understanding of reflection and admitted to having been engaging in various forms of reflective practice.

Concerning the perception about the usefulness of reflection, respondents were required to grade from 1 to 5 statements describing the essence or importance of reflection; 1-very useful, 2-useful, 3-somehow useful, 4-not all that useful, and 5-not useful at all. From the study, it was found that the nursing students' responses for this study were concentrated on 1-3 only. This is evident by the fact that $42(68.9 \%)$ of the students agreed that reflections represent very useful in critical thinking skill development, $23(37.7 \%)$ perceived reflection as useful in the synthesis of classroom and clinical knowledge, six $(9.8 \%)$ perceived reflection as useful in self-awareness creation, 44 $(72.1 \%)$ said reflection is very useful in professional growth and promotion of professional behaviours and $11(18.0 \%)$ said reflection is useful in the creation of awareness of emotional responses, personal bias and beliefs among others.

The overall scoring of the students using the items mentioned above showed that $10 \%$ of the students have a moderate positive perception about the usefulness of reflection and $90 \%$ had a good positive perception about the usefulness of reflective practice. This indicated a $100 \%$ positive perception of respondents about the use of reflection.

The above finding is in line with scientific evidence on the value of reflective practice in nursing. Researchers believe that nurses who reflect seem "to do better" in delivering nursing care by learning from their own experiences (Adams, 2018). Reflection, when used effectively, allows the student nurse to derive and create new knowledge from reformed thought processes (Mahlanze \& Sibiya, 2017; Naber \& Wyatt, 2014; Reljić et al., 2019; Ruiz-López et al., 2015).

Reflection is essential in allowing student nurses to solve complex problems related to their practice. Being a reflective practitioner is similarly important to allow the student to learn, to solve problems, to define and redefine their own belief and value systems (Mirlashari et al., 2017; Naber \& Wyatt, 2014).

\section{CONCLUSION}

Reflection is a very useful professional and personal development tool that yields positive care and learning outcomes when effectively practised. It is an integral part of nursing education because it aids in the development of critical thinking skills, which is especially important in this era of COVID 19. Teaching and learning practices should encourage students to use reflective practices in their daily lives, especially when providing patient care in healthcare settings.

\section{RECOMMENDATIONS}

1. The results of this study will aid policymakers and nursing curriculum developers in making important decisions based on empirical evidence to adjust policy in curriculum development and transform professional nursing insights on the need to know and practice reflectively. 
American Journal of Health, Medicine and Nursing Practice

ISSN 2520-4017 (Online)

Vol.6, Issue 3, pp 39 - 52, 2021

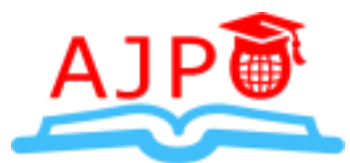

$\underline{\text { www.ajpojournals.org }}$

2. Teaching and learning methodologies that produce nursing graduates with critical thinking abilities and reflective practices, which are essential for providing effective care, should be considered.

3. Clinical staff and educators should build a collection of reflective exemplars by gaining insights into what influences students' learning in the classroom and clinical setting, as well as how they perceive events.

4. There is a need to create successful clinical learning environments that will aid in the development of a cadre of nurses who will help to boost the profession's sagging reputation, especially in this COVID-19 pandemic period.

5. Further research should be conducted on the experience and use of reflection among nursing educators and clinical facilitators

\section{REFERENCES}

Achi, M. M., Neji, O. I., Lydia O, O., Felicia, L., Victoria K, U., Mary, O.-A., \& Catherine, C. (2016). Knowledge and Application of Reflective Practice: A Tool for Meaningful Nursing Practice Among Nurses in University of Calabar Teaching Hospital Cross River State Nigeria. International Journal of Nursing, 2(2), 26-38. www.eajournals.org

Adams, G. (2018). The use of reflection in practice: The experiences of 3rd year Baccalaureus Technologiae (BTech) nursing students at a nursing education institution in the Western Cape Province. Stellenbosch: Stellenbosch University.

Agyeman-Yeboah, J., Korsah, K. A., \& Okrah, J. (2017). Factors that influence the clinical utilization of the nursing process at a hospital in Accra, Ghana. BMC Nursing, 16(1), 1-7.

Anderson, B. (2019). Reflecting on the communication process in health care. Part 1: clinical practice - breaking bad news. British Journal of Nursing, 28(13), 858-863.

Boso, C. M., van der Merwe, A. S., \& Gross, J. (2020). Critical thinking skills of nursing students: Observations of classroom instructional activities. Nursing Open, 7(2), 581-588.

Bruni-Bossio, V. \& Delbaere, M. (2021). Not everything important is taught in the classroom: Using cocurricular professional development workshops to enhance student careers. Journal of Management Education, 45(2), 265-292.

Cecilia, K. Y. C. \& Katherine, K. W. L. (2020). Reflection literacy: A multilevel perspective on the challenges of using reflections in higher education through a comprehensive literature review. Educational Research Review, 100376.

d'Aquin, V. (2020). Reflections of a COVID-19 Graduate Nurse Student. The Journal for Nurse Practitioners, 16(8), 641.

Graue, M., Rasmussen, B., Iversen, A. S., \& Dunning, T. (2015). Learning transitions-a descriptive study of nurses' experiences during advanced level nursing education. BMC Nursing, 14(1), 1-9.

Gross, J. V., Mohren, J., \& Erren, T. C. (2021). COVID-19 and healthcare workers: A rapid systematic review into risks and preventive measures. BMJ Open, 11(1), 1-13. https://doi.org/10.1136/bmjopen-2020-042270 
American Journal of Health, Medicine and Nursing Practice

ISSN 2520-4017 (Online)

Vol.6, Issue 3, pp 39 - 52, 2021

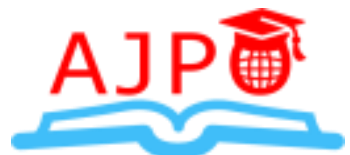

Www.ajpojournals.org

Mahlanze, H. T., \& Sibiya, M. N. (2017). Perceptions of student nurses on the writing of reflective journals as a means for personal, professional and clinical learning development. Health SA Gesondheid, 22, 79-86.

Mirlashari, J., Warnock, F., \& Jahanbani, J. (2017). The experiences of undergraduate nursing students and self-reflective accounts of first clinical rotation in pediatric oncology. Nurse Education in Practice, 25, 22-28. https://doi.org/10.1016/j.nepr.2017.04.006

Naber, J., \& Wyatt, T. H. (2014). The effect of reflective writing interventions on the critical thinking skills and dispositions of baccalaureate nursing students. Nurse Education Today, 34(1), 67-72. https://doi.org/10.1016/j.nedt.2013.04.002

Nelumbu, L. N. (2013). An educational programme to facilitate reflective practice for registered nurses in training hospitals in Windhoek.

Reljić, N. M., Pajnkihar, M., \& Fekonja, Z. (2019). Self-reflection during first clinical practice: The experiences of nursing students. Nurse Education Today, 72, 61-66.

Ruiz-López, M., Rodriguez-García, M., Villanueva, P. G., Márquez-Cava, M., García-Mateos, M., Ruiz-Ruiz, B., \& Herrera-Sánchez, E. (2015). The use of reflective journaling as a learning strategy during the clinical rotations of students from the faculty of health sciences: An action-research study. Nurse Education Today, 35(10), e26-e31. https://doi.org/10.1016/j.nedt.2015.07.029

Tashiro, J., Shimpuku, Y., Naruse, K., \& Matsutani, M. (2013). Concept analysis of reflection in nursing professional development. Japan Journal of Nursing Science, 10(2), 170-179.

Ulenaers, D., Grosemans, J., Schrooten, W., \& Bergs, J. (2021). Clinical placement experience of nursing students during the COVID-19 pandemic: A cross-sectional study. Nurse Education Today, 99, 104746.

Van Rensburg, G. H., Botma, Y., Heyns, T., \& Coetzee, I. M. (2018). Creative strategies to support student learning through reflection. South African Journal of Higher Education, 32(6), 604618.

Yiridomoh, G. Y., Dayour, F., \& Bonye, S. Z. (2020). Evidence-based practice and rural health service delivery: knowledge and barriers to adoption among clinical nurses in Ghana. Rural Society, 29(2), 134-149. 